\title{
Tratamiento de los melanomas cutáneos de la cabeza y el cuello. Estado actual
}

\section{The current state of treatment for cutaneous melanoma of the head and neck}

\author{
P.M. Villarreal Renedo , J. Mateo Arias², C. Álvarez Cuesta ${ }^{3}$, E. Rodríguez Díaz \\ A. Fernández Bustillo4, A.J. Morillo Sánchez²
}

Resumen: Objetivo. Demostrar nuestra experiencia en el tratamiento del melanoma cutáneo de cabeza y cuello, así como en el estadiaje ganglionar regional a través de la detección y biopsia de los ganglios centinelas cervicofaciales.

Métodos. Analizamos los casos de melanoma de cabeza y cuello tratados a lo largo de los últimos 3 años. Los pacientes que nos fueron enviados con metástasis cervicofaciales fueron tratados mediante linfadenectomías cervicales acompañadas de parotidectomías si existían ganglios peri o intraparotídeos afectos. En los pacientes enviados sin resecar el tumor primario, tras la biopsia preoperatoria y el estudio de extensión, se realizó la identificación y exéresis de los ganglios centinelas cervicofaciales, la resección del primario y la reconstrucción del defecto creado mediante colgajos locorregionales.

Resultados. El melanoma se asocia con un excelente pronóstico a largo plazo si se detecta y trata en estadios precoces. La técnica de la identificación y exéresis de los ganglios centinelas cervicofaciales es factible en los melanomas de cabeza y cuello.

Conclusión. La técnica de detección y biopsia de los ganglios centinelas regionales se considera el procedimiento de elección para realizar el estadiaje ganglionar regional en el melanoma de cabeza y cuello. Permite aumentar la eficacia y sensibilidad del estudio histopatológico, al seleccionar los ganglios linfáticos cervicofaciales con mayor probabilidad de encontrar focos metastásicos.

Palabras clave: Melanoma cutáneo; Cabeza y cuello; Estadiaje cervical; Ganglio centinela.

Recibido: 20 de enero de 2005

Aceptado: 22 de junio de 2005

1 Médico adjunto. Servicio de Cirugía Oral y Maxilofacial. Hospital Universitario Central de Asturias. Oviedo, España.

2 Médico adjunto. Servicio de Cirugía Oral y Maxilofacial. Hospital Universitario Infanta Cristina de Badajoz, España.

3 Médico adjunto. Servicio de Dermatología. Hospital de Cabueñes. Gijón, España.

4 Cirujano Oral y Maxilofacial. Práctica privada. Pamplona, España.

Correspondencia:

Pedro M ${ }^{a}$ Villarreal Renedo

Servicio de Cirugía Oral y Maxilofacial.

Hospital Universitario Central de Asturias.

C/ Celestino Villamil s/n - 33006- Oviedo (Asturias), España.

E-mail: pedrovillarreal@eresmas.com
Abstract: Objective. To demonstrate our experience in the treatment of head and neck cutaneous melanoma and the regional lymph nodes staging, by the sentinel lymph nodes biopsy technique.

Methods. We analyze the cases of head and neck cutaneous melanoma treated during the last 3 years. Patients with cervical and/or facial metastases were treated by neck dissection plus parotidectomy if peripheral or intra-parotid nodes were affected. In the patients with primary tumours, a preoperatory biopsy and a whole body extension study were performed. After that, the cervical and facial sentinel lymph nodes and the primary tumour were resected. The defects created were reconstructed by means of local or regional cutaneous flaps.

Results. Cutaneous melanoma associates with an excellent long-term prognosis when is detected and treated in a precocious stage. The cervical and facial sentinel lymph nodes biopsy technique is feasible in head and neck cutaneous melanomas.

Conclusion. Sentinel node biopsy technique is considered the elective procedure for head and neck cutaneous melanoma regional staging. It improves the effectiveness and sensibility of the histopathologic study, due to the capacity to select the cervical and facial lymphatic nodes with more probability of have metastases.

Key words: Cutaneous melanoma; Head and Neck; Cervical Stage; Sentinel lymph node. 


\section{Introducción}

El melanoma cutáneo (MC) es una neoplasia agresiva, de naturaleza caprichosa y traicionera, con altas posibilidades de curación cuando se diagnostica precozmente, pero con un pronóstico infausto en estadios avanzados. ${ }^{1,2}$ La región de la cabeza y el cuello presenta la mayor incidencia y tasa de mortalidad por MC de toda la superficie corporal. ${ }^{3}$ En ella se desarrollan un tercio (20-33\%) de estos tumores, aún cuando su superficie sólo supone un $9 \%$ del organismo. ${ }^{4,5}$

La cirugía constituye la terapéutica electiva para el MC de cabeza y cuello. El debate se centra actualmente sobre los márgenes de resección y la necesidad de realizar disecciones ganglionares cervicofaciales profiláctico-terapéuticas. ${ }^{1}$

El estado histopatológico de los ganglios linfáticos regionales se considera hoy en día el principal determinante pronóstico por encima del espesor de Breslow, motivo por el que se debe realizar siempre el estadiaje de los mismos. ${ }^{6}$ Los pacientes que presentan enfermedad metastásica en los ganglios cervicofaciales requieren una disección ganglionar cervical. Si existen metástasis en los ganglios peri o intraparotídeos debe realizarse, además, una parotidectomía. En los pacientes sin evidencia clínico-radiológica de metástasis (T2, $\mathrm{T} 3$ y T4, N0) el estadiaje regional debe establecerse mediante la linfadenectomía selectiva de los ganglios centinelas (GC) cervicofaciales. $^{7}$

La detección, exéresis y biopsia de los GC se ha convertido en el procedimiento electivo para el tratamiento del MC de cabeza y cuello sin adenopatías metastásicas evidentes. La técnica permite realizar un estadiaje cervical más preciso, al ser capaz de detectar la presencia de metástasis ganglionares subclínicas o microscópicas, identificando los pacientes que precisan una linfadenectomía y el posterior tratamiento adyuvante. ${ }^{6,8-11}$ Su relevancia es de tal magnitud, que sus resultados han sido incorporados en la última versión del sistema de estadiaje de la American Joint Committee on Cancer (AJCC, Tabla 1). ${ }^{6}$

\section{Objetivos}

Mostrar nuestra experiencia en el tratamiento del melanoma cutáneo de la cabeza y el cuello, así como en el estadiaje regional a través de la técnica de detección y biopsia de los ganglios centinelas cervicofaciales.

Demostrar la posibilidad de realizar la localización, disección y exéresis de los ganglios centinelas peri e intraparotídeos, a pesar de su inherente dificultad debido a su reducido tamaño y el elevado riesgo de lesionar el nervio facial.

\section{Material y método}

Hemos tenido la oportunidad de tratar a 21 pacientes, diagnosticados de melanomas cutáneos de cabeza y cuello, en los Servicios de Cirugía Oral y Maxilofacial del Hospital Infanta Cristina de Badajoz y del Hospital de Cabueñes en Gijón. Desgraciada-

\section{Introduction}

The cutaneous melanoma (CM) is an aggressive neoplasm, with a capricious and treacherous nature. It has a high cure rate if diagnosed rapidly, but for advanced stages the prognosis is gloomy ${ }^{1,2}$ Of all the body surface, the head and neck are the areas with the greatest incidence and mortality rates as a result of CM. ${ }^{3}$ Here, a third (20-33\%) of these tumors develop, even when this surface area only represents $9 \%$ of the organism. ${ }^{4,5}$

Surgery is the procedure of choice for $C M$ of the head and neck. There is current debate as to the resection margins and the need for carrying out cervicofacial prophylactic/therapeutic lymph node dissection. ${ }^{1}$

The histopathologic state of the regional lymph nodes is considered today the main factor determining prognosis, more so than Breslow's thickness, and for this reason staging should always be carried out. ${ }^{6}$ Those patients with metastatic disease of lymph nodes of the head and neck require cervical lymph node dissection. If there is metastasis of the periparotid or intraparotid lymph nodes, a parotidectomy should also be carried out. In those patients where there is no clinical/radiological evidence of metastasis (T2, T3 and T4 NO) regional staging should be established by means of a selective lymphadenectomy of sentinel lymph nodes (SN) of the head and neck.

The detection, excision and biopsy of SN has become the procedure of choice for treating CM of the head and neck when there is no clear metastatic adenopathy. The technique allows carrying out more precise neck staging, as it is possible to detect the presence of subclinical or microscopic lymph node metastasis. Those patients requiring a lymphadenectomy and posterior adjuvant treatment are identified. $6,8,9,10,11$ Its relevance is so considerable that its results have been incorporated into the latest staging system of the American Joint Committee on Cancer (AJCC, Table 1). 6

\section{Objectives}

To show our experience in the treatment of cutaneous melanoma of the head and neck, as well as regional staging through detection techniques and biopsies of sentinel lymph nodes of the head and neck.

To show how locating, dissecting and removing periparotid and intraparotid sentinel lymph nodes is possible, despite the inherent difficulty due to their reduced size and the high risk of harming facial nerves.

\section{Material and method}

We have had the opportunity of treating 21 patients, diagnosed with cutaneous melanoma of the head and neck, in the Service of Oral and Maxillofacial Surgery of the Infanta Cristina Hospital in Badajoz and the Cabueñes Hospital in Gijón. Unfortunately, 15 of the patients were sent to us with 
Tabla 1. Versión final del Sistema de estadiaje de la American Joint Committee on Cancer (AJCC) para el melanoma cutáneo.

\begin{tabular}{|c|c|c|c|c|c|c|c|}
\hline \multicolumn{4}{|c|}{ Estadio } & \multicolumn{4}{|l|}{ Subtipo } \\
\hline $\mathrm{T} 1$ & \multicolumn{3}{|l|}{$\leq 1,0 \mathrm{~mm}$} & \multicolumn{4}{|c|}{$\begin{array}{l}\text { a: Sin ulceración } \\
\text { b: Con ulceración o nivel IV o V de Clark }\end{array}$} \\
\hline T2 & \multicolumn{3}{|l|}{$1,01-2,0 \mathrm{~mm}$} & $\begin{array}{l}\text { a: } \operatorname{Sin} \text { ulc } \\
\text { b: } \operatorname{Con} u\end{array}$ & $\begin{array}{l}\text { eración } \\
\text { ceración }\end{array}$ & & \\
\hline T3 & \multicolumn{3}{|l|}{$2,01-4,0 \mathrm{~mm}$} & $\begin{array}{l}\text { a: } \operatorname{Sin} u l c \\
\text { b: Con ul }\end{array}$ & $\begin{array}{l}\text { eración } \\
\text { ceración }\end{array}$ & & \\
\hline T4 & \multicolumn{3}{|l|}{$>4 \mathrm{~mm}$} & $\begin{array}{l}\text { a: } \operatorname{Sin} \text { ulc } \\
\text { b: Con ul }\end{array}$ & $\begin{array}{l}\text { eración } \\
\text { ceración }\end{array}$ & b: Con ulceración & \\
\hline N1 & \multicolumn{3}{|l|}{1 ganglio } & \\
\hline N2 & \multicolumn{3}{|l|}{ 2-3 ganglios } & \multicolumn{4}{|c|}{$\begin{array}{l}\text { a: Micrometástasis } \\
\text { b: Macrometástasis } \\
\text { c: Metástasis en tránsito/satelitosis } \\
\text { sin afectación ganglionar }\end{array}$} \\
\hline N3 & \multicolumn{3}{|c|}{$\begin{array}{l}4 \text { o más ganglios, } \\
\text { conglomerado ganglionar, } \\
\text { combinación de ganglios } \\
\text { afectos y metástasis en } \\
\text { tránsito/satelitosis o } \\
\text { ulceración }\end{array}$} & & & & \\
\hline M1 & \multicolumn{3}{|c|}{$\begin{array}{l}\text { Metástasis cutánea a } \\
\text { distancia, subcutáneas } \\
\text { o ganglionares }\end{array}$} & \multicolumn{4}{|c|}{ LDH normal } \\
\hline M2 & \multicolumn{3}{|c|}{ Metástasis pulmonares } & \multicolumn{4}{|c|}{ LDH normal } \\
\hline \multirow[t]{2}{*}{ M3 } & \multicolumn{3}{|c|}{$\begin{array}{l}\text { Otras metástasis viscerales } \\
\text { Cualquier metástasis }\end{array}$} & \multicolumn{4}{|c|}{ LDH normal } \\
\hline & \multicolumn{3}{|c|}{ Estadio clínico } & \multicolumn{4}{|c|}{ Estadio histológico } \\
\hline 0 & Tis & N0 & M0 & 0 & Tis & N0 & M0 \\
\hline Ia & $\mathrm{Tla}$ & No & M0 & Ia & Tla & No & M0 \\
\hline $\mathrm{Ib}$ & $\begin{array}{l}\mathrm{T} 1 \mathrm{~b} \\
\mathrm{~T} 2 \mathrm{a}\end{array}$ & No & M0 & $\mathrm{Ib}$ & $\begin{array}{l}\text { T1b } \\
\text { T2a }\end{array}$ & No & M0 \\
\hline IIa & $\begin{array}{l}\mathrm{T} 2 \mathrm{~b} \\
\mathrm{~T} 3 \mathrm{a}\end{array}$ & No & M0 & IIa & $\begin{array}{l}\mathrm{T} 2 \mathrm{~b} \\
\mathrm{~T} 3 \mathrm{a}\end{array}$ & No & M0 \\
\hline IIb & $\begin{array}{l}\text { T3b } \\
\text { T4a }\end{array}$ & No & M0 & $\mathrm{IIb}$ & $\begin{array}{l}\text { T3b } \\
\text { T4a }\end{array}$ & No & M0 \\
\hline IIc & T4́b & N0 & M0 & IIc & T4b & No & M0 \\
\hline IIIa & Cualquier T1-4a & $\mathrm{N} 1 \mathrm{~b}$ & M0 & IIIa & T1-4a & $\mathrm{Nla}$ & M0 \\
\hline IIIb & Cualquier T1-4a & $\mathrm{N} 2 \mathrm{~b}$ & M0 & IIIb & $\begin{array}{l}\text { T1-4a } \\
\text { T1-4a }\end{array}$ & $\begin{array}{l}\mathrm{N} 1 \mathrm{~b} \\
\mathrm{~N} 2 \mathrm{a}\end{array}$ & $\begin{array}{l}\text { M0 } \\
\text { M0 }\end{array}$ \\
\hline IIIc & $\begin{array}{l}\text { Cualquier T } \\
\text { Cualquier T }\end{array}$ & $\begin{array}{l}\mathrm{N} 2 \mathrm{c} \\
\mathrm{N} 3\end{array}$ & M0 & IIIc & $\begin{array}{l}\text { Cualquier T } \\
\text { Cualquier T }\end{array}$ & $\begin{array}{c}\mathrm{N} 2 \mathrm{~b}, \mathrm{~N} 2 \mathrm{c} \\
\mathrm{N} 3\end{array}$ & \\
\hline IV & Cualquier $\mathrm{T} \quad \mathrm{Cu}$ & ualquier $\mathrm{N}$ & M1 & IV & Cualquier T & Cualquier I & NM1 \\
\hline
\end{tabular}

Tabla 1. Final version of the staging system of the American Joint Committee on Cancer (AJCC) for cutaneous melanoma.

\begin{tabular}{|c|c|c|}
\hline & Stage & Subtipo \\
\hline \multirow[t]{2}{*}{$\mathrm{T} 1$} & $\leq 1.0 \mathrm{~mm}$ & a: No ulceration \\
\hline & & b: With ulceration or Clark's level IV or $\mathrm{V}$ \\
\hline \multirow[t]{2}{*}{$\mathrm{T} 2$} & $1.01-2.0 \mathrm{~mm}$ & a: No ulceration \\
\hline & & b: With ulceration \\
\hline \multirow[t]{2}{*}{ T3 } & $2.01-4.0 \mathrm{~mm}$ & a: No ulceration \\
\hline & & b: With ulceration \\
\hline \multirow[t]{2}{*}{ T4 } & $>4 \mathrm{~mm}$ & a: No ulceration \\
\hline & & b: With ulceration \\
\hline \multirow[t]{2}{*}{ N1 } & 1 ymph node & a: Micrometastasis \\
\hline & & b: Macrometastasis \\
\hline \multirow[t]{3}{*}{ N2 } & 2-3 lymph nodes & a: Micrometastasis \\
\hline & & b: Macrometastasis \\
\hline & & c: Metastasis in-transit/satellitosis \\
\hline
\end{tabular}

N3 or more lymph nodes, ganglionic conglomeration, combination of lymph nodes involved and metastasis in-transit/satellitosis or ulceration

$\begin{array}{lll}\text { M1 } & \begin{array}{l}\text { Distant, subcutaneous or } \\ \text { ganglionic cutaneous } \\ \text { metastasis }\end{array} & \text { Normal LDH } \\ \text { M2 } & \text { Metastasis to the lungs } & \text { Normal LDH } \\ \text { M3 } & \text { Visceral metastasis } & \text { Normal LDH } \\ & \text { Any type of metastasis } & \text { High LDH }\end{array}$

\begin{tabular}{llll|cccc}
\multicolumn{4}{c}{ Clinical stage } & \multicolumn{5}{c}{ Histologic stage } \\
\hline 0 & Tis & N0 & M0 & 0 & Tis & N0 & M0 \\
Ia & T1a & N0 & M0 & Ia & T1a & N0 & M0 \\
Ib & T1b & N0 & M0 & Ib & T1b & N0 & M0 \\
& T2a & & & & T2a & & \\
IIla & T2b & N0 & M0 & IIa & T2b & N0 & M0 \\
& T3a & & & & T3a & & \\
IIb & T3b & N0 & M0 & IIb & T3b & N0 & M0 \\
& T4a & & & & T4a & & \\
IIc & T4b & N0 & M0 & IIc & T4b & N0 & M0 \\
IIIa & Any T1-4a & N1b & M0 & IIIa & T1-4a & N1a & M0 \\
IIIb & Any T1-4a & N2b & M0 & IIIb & T1-4a & N1b & M0 \\
& & & & & T1-4a & N2a & M0 \\
IIIc & Any T & N2c & M0 & IIIc & Any T & N2b,N2c & M0 \\
& Any T & N3 & & & Any T & N3 & \\
IV & Any T & Any N & M1 & IV & Any T & Any N & M1
\end{tabular}

mente, 15 de ellos fueron enviados presentando metástasis linfáticas cervicofaciales tras la resección del tumor primario en otros Servicios. Sólo seis pacientes acudieron sin tratar el tumor primario y sin presentar metástasis linfáticas regionales. En estos últimos, el diagnóstico se corroboró histológicamente mediante una biopsia incisional, realizando el estudio de extensión mediante la exploración clínica, analítica completa (hemograma y bioquímica incluyendo fosfatasa alcalina y LDH), ${ }^{11}$ pruebas de función hepática (GOT/GPT, Gamma GT) ecografía hepática y radiografía de tórax. Si el examen clínico-radiológico evidenciaba algún signo de afectación metastásica se realizaron otras pruebas radiológicas (TC crá- lymphatic metastasis of the head and neck following the resection of the primary tumor in another Service. Only six patients attended with untreated primary tumors and with no regional lymphatic metastasis. Of these, the diagnosis was corroborated histologically by means of an incisional biopsy, and an extension study was carried out by means of clinical examination, and thorough testing (hemogram and biochemistry including alkaline phosphatase and $L D H)^{11}$ hepatic function tests, (GOT/GPT, Gamma GT) hepatic ultrasound and radiography of the thorax. If the clinical/radiologic test showed signs of metastasis, other radiological tests 

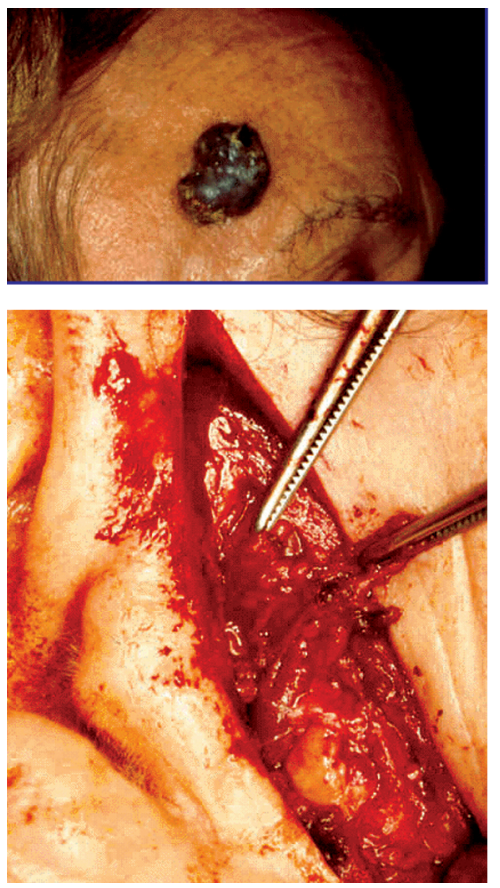
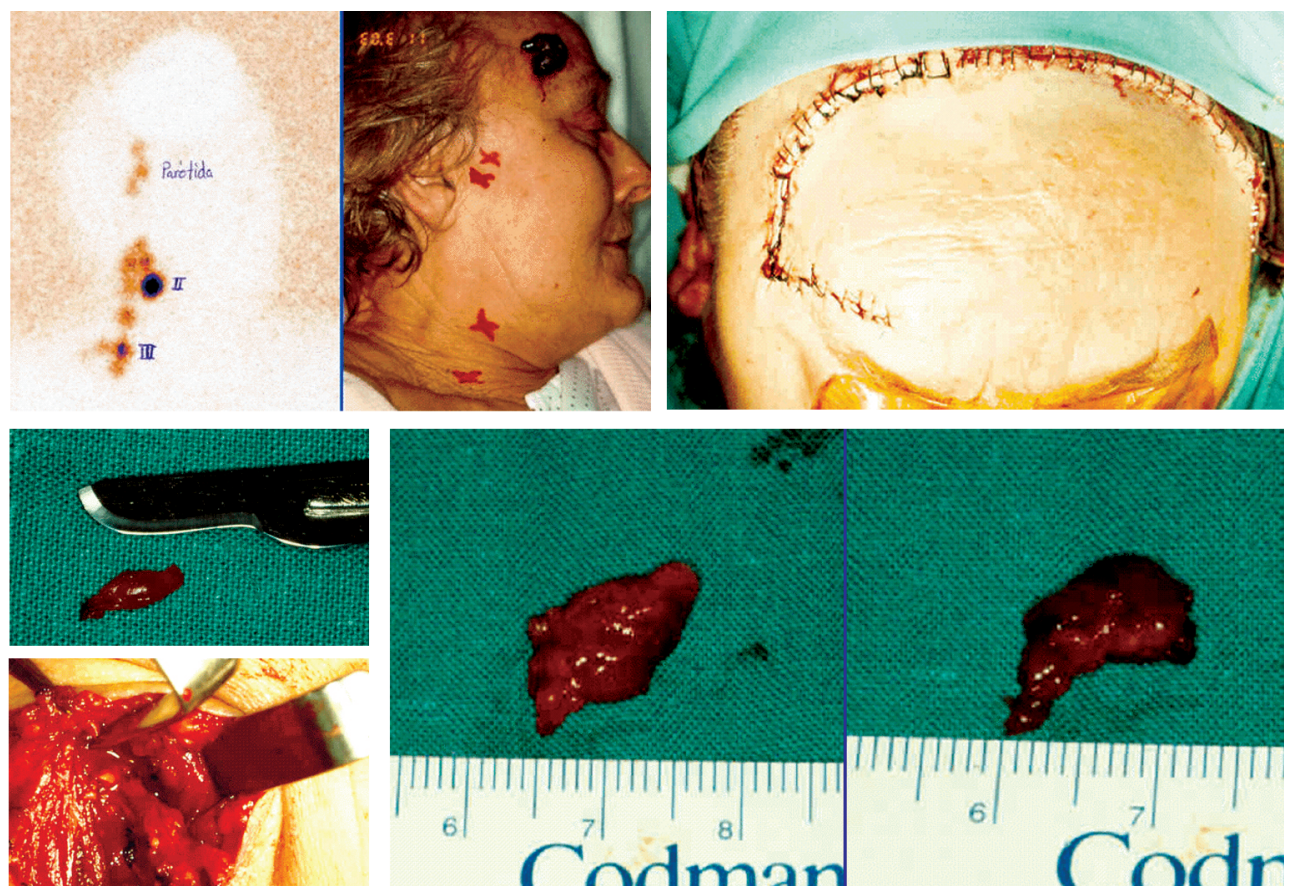

Figura 1. Paciente con melanoma nodular frontal (T3 N0 M0). Durante la linfogammagrafía (LGG) preoperatoria se identifican 4 ganglios centinelas (2 parotídeos, uno yugulodigástrico y otro yugular medio). Se realizó la resección del primario y la reconstrucción mediante un colgajo frontal de rotación. Se identificaron y resecaron los ganglios centinelas mediante la sonda quirúrgica gamma.

Figure 1. Patient with frontal node melanoma (T3 NO MO). During the preoperative lymphoscintigraphy (LSG) 4 sentinel lymph noses were identified (2 parotid, one jugulodigastric and another jugular half). The primary tumor was resected and reconstruction was carried out by means of a frontal turnover flap. The sentinel lymph nodes were identified by means of a surgical gamma probe.

neo-tóraco-abdominal) o de medicina nuclear (gammagrafía ósea). El cuello fue estadiado clínica y radiológicamente (TC, AJCC-UICC) en todos los casos.

A los pacientes con metástasis linfáticas cervicofaciales se les realizó una disección cervicofacial funcional o radical modificada, incluyendo una parotidectomía en los casos que existía afectación de los ganglios peri e intraparotídeos.

El estadiaje cervicofacial en los pacientes sin metástasis regionales se realizó mediante la linfadenectomía selectiva de los ganglios centinelas (GC) cervicofaciales. Estos GC se identificaron mediante una linfogammagrafía preoperatoria y se localizaron intraoperatoriamente mediante una sonda quirúrgica gamma (Scintiprobe Mr-100, Pol.hi.tech, Italia). Además de la exéresis de los GC, procedimos a la resección y reconstrucción del tumor primario cutáneo mediante colgajos locorregionales (Figs. 1, 2, 3 y 4). Todos los GC fueron estudiados mediante seccionamiento múltiple y tinciones con hematoxilina y eosina e inmunohistoquímica utilizando anticuerpos anti-HMB 45, S-100 y Melan A.

La presencia de metástasis en algún GC obligaría a realizar una disección cervical funcional terapéutica diferida. En los pacientes con múltiples adenopatías metastásicas o con invasión extracapsular se complementaría el tratamiento mediante radioterapia (RT). El tratamiento con interferón $\alpha-2 b$ se indicaría en los pacientes con metástasis regionales, un Breslow intermedio-profundo ( $>2 \mathrm{~mm})$ y en tumores ulcerados (estadios II-b y III). Si apareciese enfermedad metastásica a distancia se trataría según Protocolo Oncológico. were carried out (cranium-thorax-abdomen CAT) or nuclear medicine (bone gammagraph). The neck was staged clinically and radiologically (TC, AJCC, UICC) in all cases.

All the patients with lymphatic metastasis of the head and neck underwent functional cervicofacial dissection or modified radical dissection, which included a parotidectomy in those cases when the periparotid and intraparotid lymph nodes were affected.

Head and neck staging was carried out in those patients that did not have regional metastasis by means of a selective lymphadenectomy of sentinel lymph nodes (SN) of the head and neck. These $S N$ were identified by means of a preoperative lymphoscintigraphy and they were located intraoperatively by means of a surgical gamma probe (Scintiprobe Mr-100), Pol.hi.tech, Italy). As well as the removal of the $\mathrm{SN}$, the primary cutaneous tumor was then resected and reconstructed with locoregional flaps (Figs. 1, 2, 3 and 4). All the $\mathrm{SN}$ were studied by means of multiple sectioning and staining with hematoxylin and eosin and by means of immunohistochemistry using the HMB 45, S 100 and Melan A antibodies.

The presence of metastasis in some SN led to a deferred therapeutic functional cervical dissection being necessary. In patients with multiple metastatic adenopathy or with extracapsular invasion additional radiotherapy therapy (RT) was given. Treatment with interferon $\alpha-2 b$ is indicated in patients with regional metastasis, an intermediate-deep Breslow thick- 

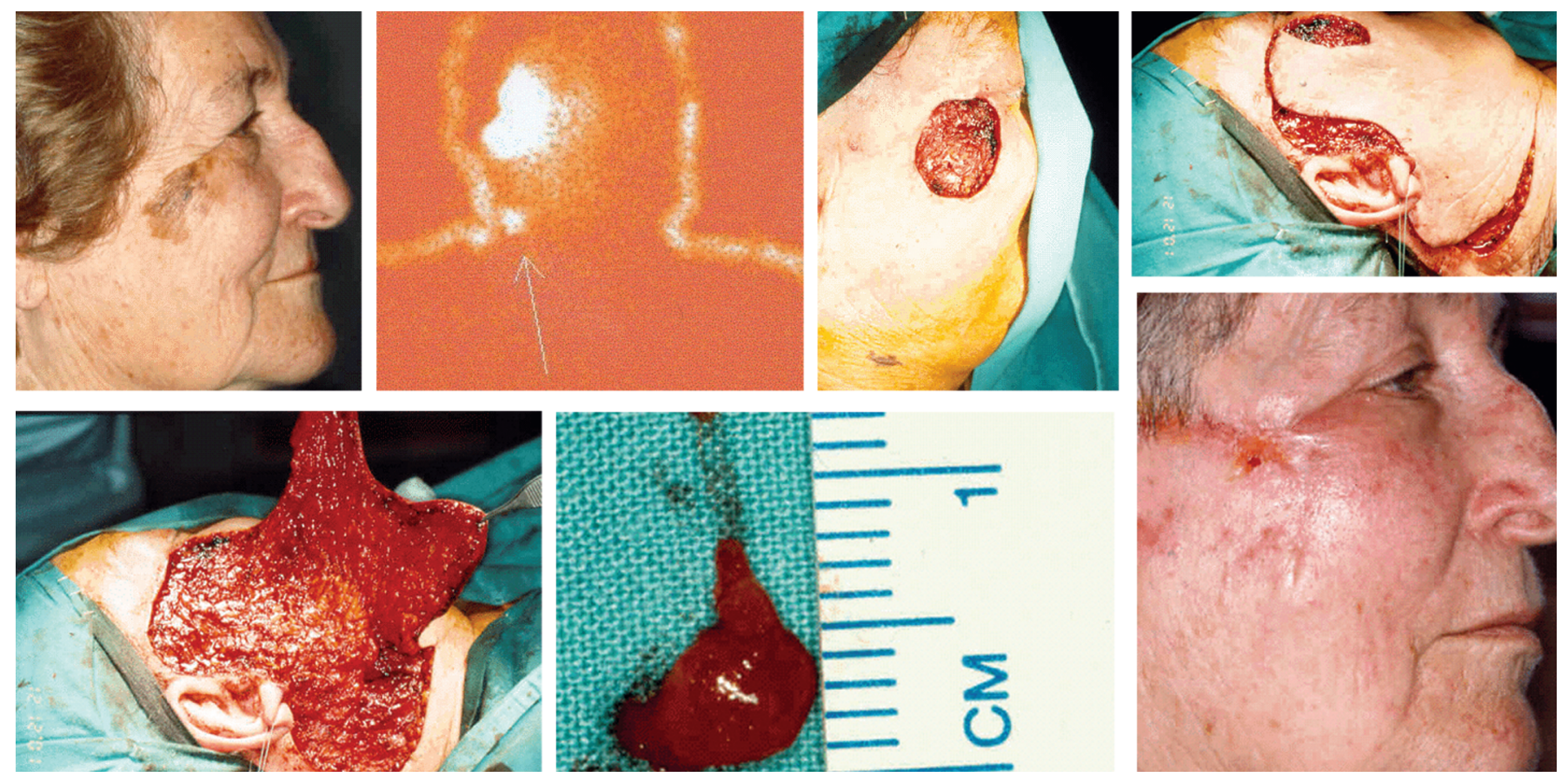

Figura 2. Paciente con léntigo maligno melanoma malar (T1 a NO M0). Durante la linfogammagrafía (LGG) preoperatoria se identifican 3 ganglios centinelas parotídeos. Se realizó la resección del primario y la reconstrucción mediante un colgajo cervicofacial. Se identificaron y resecaron los ganglios centinelas mediante la sonda quirúrgica gamma.

Figure 2. Patient with a lentigo malignant melanoma of the malar (T1 a NO MO). During the preoperative lymphoscintigraphy (LSG) 3 sentinel lymph nodes of the parotid were identified. The primary tumor was resected and reconstruction was carried out using a cervicofacial flap. The sentinel lymph nodes were identified a resected using a surgical gamma probe.

\section{Resultados}

El tiempo de seguimiento actual se sitúa entre 15 y 36 meses con un promedio de 29 meses. De los 15 pacientes con metástasis regionales, 8 presentaron metástasis a distancia ( 6 en pulmones, 3 en hígado y 2 en cerebro) en un tiempo promedio de 20 meses (entre 9 y 29 meses). Seis de ellos han fallecido como consecuencia de su enfermedad. De los 7 casos sin metástasis a distancia, 2 fallecieron por causas ajenas a su enfermedad, estando los 5 restantes libres de enfermedad en el momento actual.

De los 6 pacientes tratados como tumores primarios sin metástasis cervicales, cinco casos correspondían a mujeres y uno era varón. El rango de edad estaba comprendido entre 28 y 79 años con 66 años de media. En la tabla 2 se expresan las características clínicas e histológicas más importantes de cada caso.

Las linfogammagrafías (LGG) preoperatorias evidenciaron un total de 17 ganglios centinelas (GC), mientras que durante la cirugía se resecaron un total de 20 GC. Los 3 GC de más correspondían a GC peri-parotídeos pertenecientes a una paciente (no 4) en la que sólo se evidenciaron 2 GC durante la LGG y 5 GC durante la cirugía. Creemos que la resolución espacial de la LGG no permitió discriminar la presencia de varios GC en un mismo nivel ganglionar (Tabla 3).

En cada paciente obtuvimos un promedio de $3,3 \mathrm{GC}$ con un rango entre 1 y 5 GC. La relación de GC localizados durante la cirugía por niveles cervicales, el resultado histopatológico y el tipo de tratamiento aplicado se expresan en la tabla 2. Obtuvimos GC bilaterales en un paciente, de los dos con tumores localizados en la ness $(<2 \mathrm{~mm})$ and in ulcerated tumors (stages II-b and III). If distant metastasis appeared this was treated according to the Oncological Protocol.

\section{Results}

The current follow-up is between 15 and 36 months with an average of 29 months. Of the 15 patients with regional metastasis, eight had distant metastasis (six in the lungs, three in the liver and two in the brain) in an average time of 20 months (between 9 and 29 months). Six died as a result of their illness. Of the seven cases that did not have distant metastasis, two died due to consequences that were unrelated to their illness, with the remaining five currently being disease free.

Of the six patients treated for primary tumors that did not have cervical metastasis, five cases corresponded to women and one to $a$ man. The age range was between 28 and 79 years with 66 being the average age. Table 2 shows the most important clinical and histological characteristics of each case.

The preoperative lymphoscintigraphies (LSG) showed a total of 17 sentinel lymph nodes (SN), while during the surgery a total of 20 SN were resected. The three extra SN were periparotid SN of a female patient (№4) that only had two SN visible during the LSG and $5 \mathrm{SN}$ during the surgery. We believe that the spatial resolution of the LSG did not allow identifying the presence of various $S \mathrm{~N}$ in the same nodal level (Table 3). 

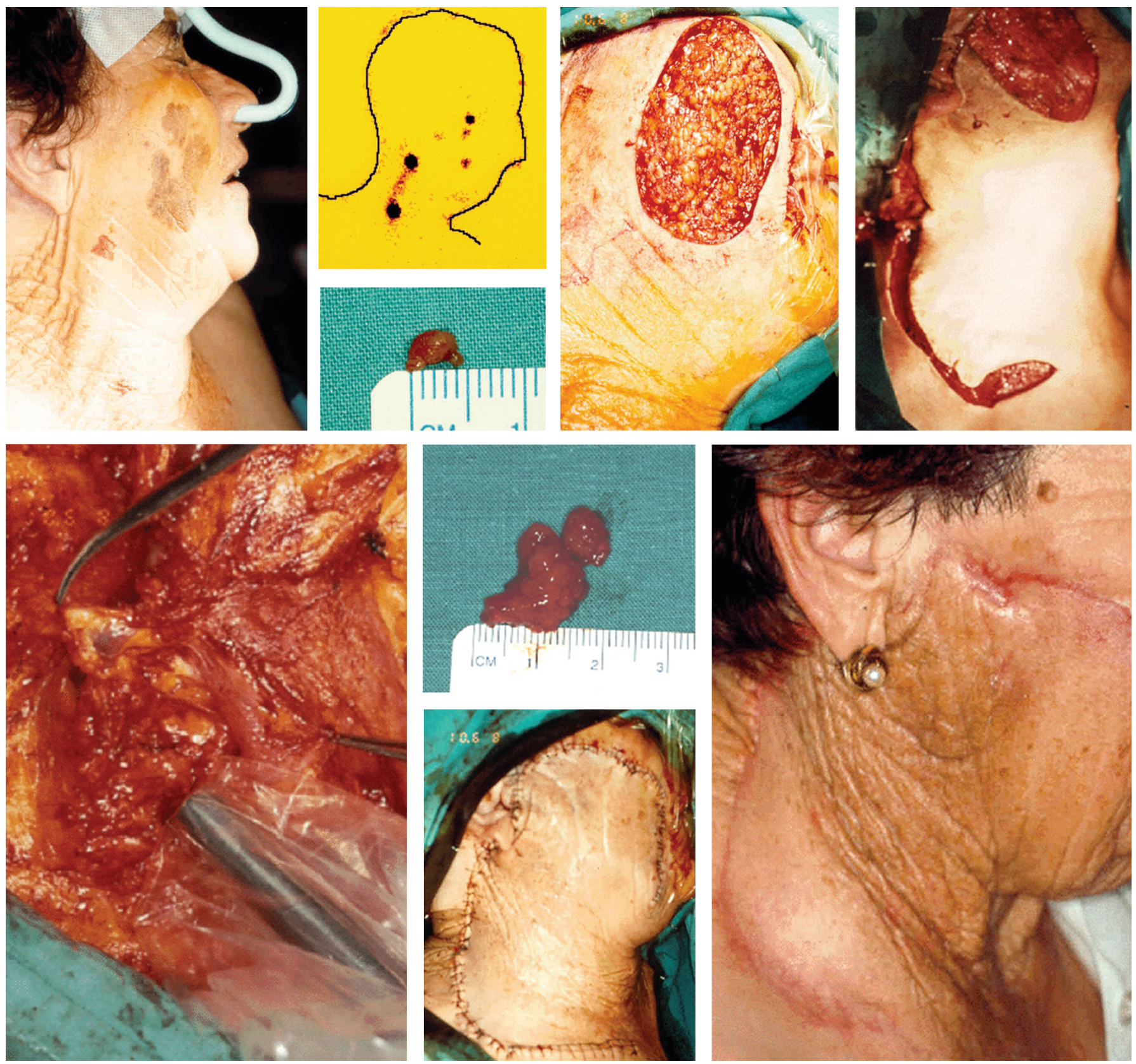

Figura 3. Paciente con léntigo maligno melanoma de la mejilla derecha ( $T 1$ a N0 M0). Durante la linfogammagrafía (LGG) preoperatoria se identifican 2 ganglios centinelas (1 parotídeo y otro en el triángulo cervical posterior). Se realizó la resección del primario y la reconstrucción mediante un colgajo cervicofacial. Se identificaron y resecaron los ganglios centinelas mediante la sonda quirúrgica gamma.

Figure 3. Patient with a lentigo malignant melanoma on the right cheek (T1 a NO MO). During the preoperative lymphoscintigraphy (LSG) 2 sentinel lymph nodes were identified (1 in the parotid and another in the posterior neck triangle). The primary tumor was resected and reconstruction was carried out with a cervicofacial flap. The sentinel lymph nodes were resected by means of a surgical gamma probe.

línea media (no 2 y 6). En los restantes casos obtuvimos sólo GC ipsilaterales. Los niveles donde más frecuentemente encontramos GC fueron los peri-parotídeos y cervicales altos. Todos los GC eran radiactivos o calientes. Sólo en 2 pacientes se inyectó azul de metileno antes de comenzar el acto quirúrgico. De los 7 GC aislados en estos casos sólo 2 se encontraban teñidos de azul. En ninguno de los 20 GC se evidenció la presencia de metástasis en el estudio histopatológico. De ellos, en 19 encontramos células reticulares y dendríticas (no tumorales) teñidas tras la tinción inmunohistoquímica.
In each patient there was an average of $3.3 \mathrm{SN}$ with the range being between 1 and $5 \mathrm{SN}$. The interrelation of SN located during surgery on a cervical level, the histopathologic result and the type of treatment given appears in Table 2. Bilateral $S N$ were obtained in one patient, of both with tumors located in the midline ( $n^{\circ} 2$ and $n^{\circ} 6$ ). In the remaining cases only ipsilateral $\mathrm{SN}$ were obtained. The levels where $\mathrm{SN}$ were more commonly found were the periparotid and high cervical areas. All the SN were radioactive or hot. Only 

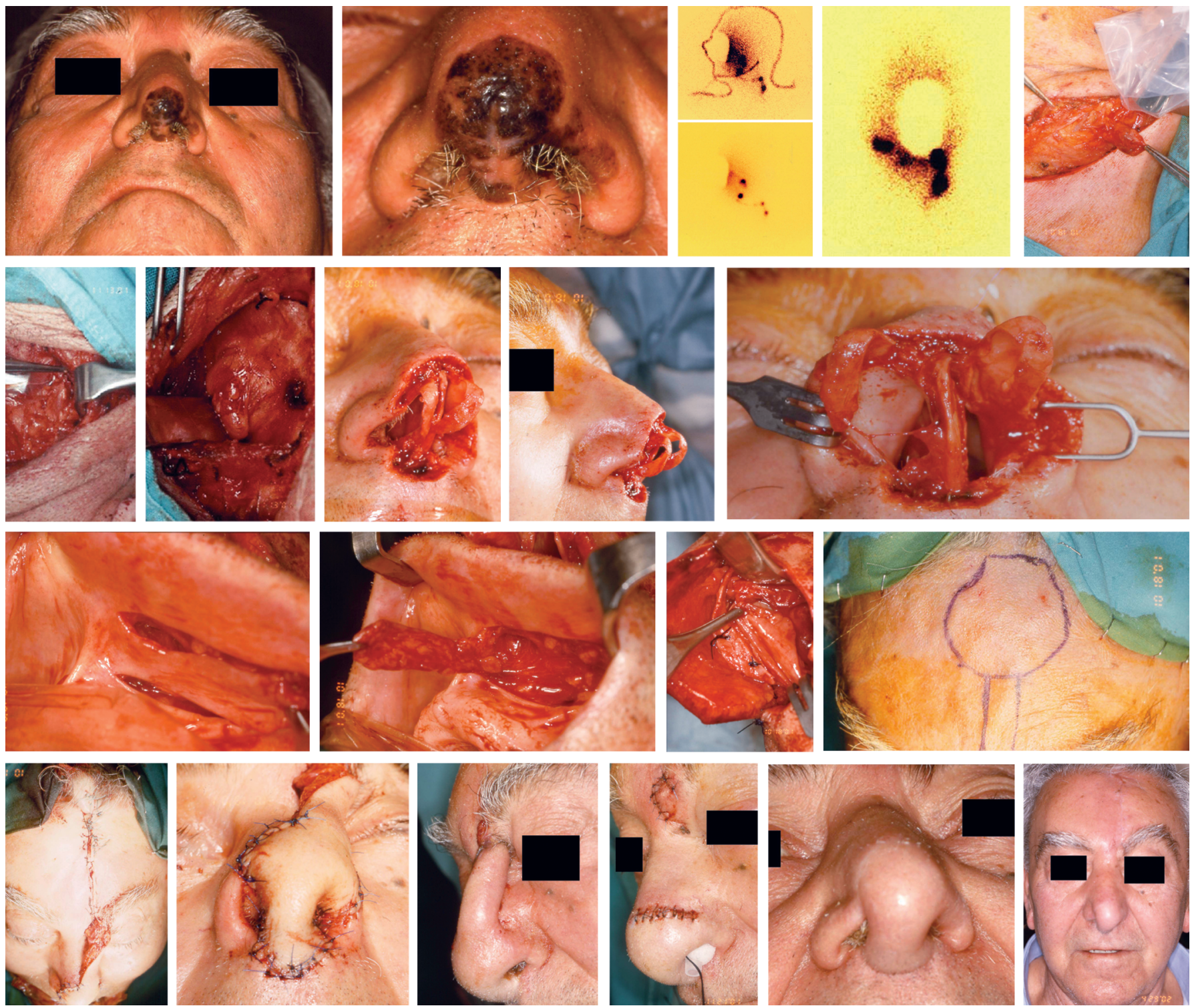

Figura 4. Paciente con melanoma nodular que afecta punta, colmuela y tabique nasales (T2b N0 M0). Durante la linfogammagrafía (LGG) preoperatoria se identifican 4 ganglios centinelas (1 nivel II derecho, 2 nivel I izquierdo y 1 nivel III izquierdo). Se realizó la resección del primario y la reconstrucción mediante un colgajo frontal y dos colgajos mucosos de labio superior. Se identificaron y resecaron los ganglios centinelas mediante la sonda quirúrgica gamma.

Figure 4. Patient with a nodular melanoma affecting the tip, columella and septum (T2b NO MO). During the preoperative lymphoscintigraphy (LSG) 4 sentinel lymph nodes were identified (1 level II on the right, 2 level I on the left and 1 level III on the left). The primary tumor was resected and reconstruction was carried out by means of a frontal flap and two mucosal flaps of the upper lip. The sentinel lymph nodes were identified and resected by means of a surgical gamma probe.

La disección cervical no se realizó en ningún paciente considerando realizado el estadiaje regional mediante los resultados del estudio histológico de los GC cervicofaciales. Todos los pacientes se encuentran libres de enfermedad en el momento actual, salvo uno (caso 4) que falleció a los 25 meses del tratamiento como consecuencia de metástasis a distancia pulmonares. Curiosamente fue la única paciente que recibió tratamiento radioterápico complementario. in 2 patients methylene blue was injected before the surgical act. Of the 7 SN that were isolated in these cases, only two were dyed blue. In none of the $20 \mathrm{SN}$ was the presence of metastases seen in the histopathologic study. Of these, 19 were found in reticular and dentritic cells (non-tumor cells) dyed after immunohistochemical staining.

No patient had cervical dissection as it was considered that regional staging had been carried out using the results of the histopathological study of the SN of the head and neck. 
Tabla 2. Características clínicas e histológicas más importantes de los pacientes enviados sin resecar el tumor primario

\begin{tabular}{|c|c|c|c|c|c|c|c|c|c|}
\hline \multirow{2}{*}{\multicolumn{2}{|c|}{ Sexo }} & \multirow[t]{2}{*}{ Edad } & \multirow[t]{2}{*}{ Localización } & \multicolumn{3}{|c|}{ Estadio } & \multicolumn{3}{|c|}{ Histología } \\
\hline & & & & T & $N$ & Clínico & Tipo & Breslow & Clark \\
\hline 1 & M & 79 & Mejilla & T 1a & N0 & IA & Léntigo & $<1 \mathrm{~mm}$ & I \\
\hline 2 & V & 70 & Nariz & Т $2 \mathrm{~b}$ & No & IIA & $\begin{array}{l}\text { Nodular } \\
\text { Ulcerado }\end{array}$ & $2 \mathrm{~mm}$ & IV \\
\hline 3 & M & 77 & Mejilla & T 1a & N0 & IA & Léntigo & $<1 \mathrm{~mm}$ & I \\
\hline 4 & M & 67 & Mejilla & Т $2 \mathrm{a}$ & N0 & IB & Nodular & $1,9 \mathrm{~mm}$ & V \\
\hline 5 & M & 77 & Frente & $\mathrm{T} 4 \mathrm{a}$ & No & IIB & Nodular & $4,6 \mathrm{~mm}$ & IV \\
\hline 6 & M & 28 & Piel Cervical & T $2 \mathrm{a}$ & N0 & IB & Nodular & $1,1 \mathrm{~mm}$ & IV \\
\hline
\end{tabular}

Tabla 2. The most important clinical and histologic characteristics of the patients referred without resection of the primary tumor

\begin{tabular}{|c|c|c|c|c|c|c|c|c|}
\hline \multirow[t]{2}{*}{ Sex } & \multirow[t]{2}{*}{ Age } & \multirow[t]{2}{*}{ Location } & \multicolumn{3}{|c|}{ Stage } & \multicolumn{3}{|c|}{ Histology } \\
\hline & & & $\mathrm{T}$ & $N$ & Clinical & Type & Breslow & Clark \\
\hline $\mathrm{F}$ & 79 & Cheek & T 1a & N0 & IA & Lentigo & $<1 \mathrm{~mm}$ & I \\
\hline M & 70 & Nose & $\mathrm{T} 2 \mathrm{~b}$ & N0 & IIA & $\begin{array}{l}\text { Nodular } \\
\text { Ulcerated }\end{array}$ & $2 \mathrm{~mm}$ & IV \\
\hline $\mathrm{F}$ & 77 & Cheek & T 1a & N0 & IA & Lentigo & $<1 \mathrm{~mm}$ & I \\
\hline F & 67 & Cheek & T $2 \mathrm{a}$ & N0 & IB & Nodular & $1.9 \mathrm{~mm}$ & V \\
\hline F & 77 & Forehead & T $4 \mathrm{a}$ & N0 & IIB & Nodular & $4.6 \mathrm{~mm}$ & IV \\
\hline F & 28 & Skin of neck & T $2 \mathrm{a}$ & N0 & IB & Nodular & $1.1 \mathrm{~mm}$ & IV \\
\hline
\end{tabular}

M: male; F: female.

\section{Discusión}

La mayor incidencia de melanoma cutáneo (MC) en la cabeza y el cuello, se atribuye a múltiples factores, como son la exposición solar y una distribución de los melanocitos en la piel 2 ó 3 veces superior. 4,5 La supervivencia de los pacientes depende de multitud de factores pronósticos interrelacionados que pueden resumirse en la idoneidad de un diagnóstico y un tratamiento precoces. Así, mientras los pacientes con estadios precoces de la enfermedad tienen tasas de curación superiores al 90\%, el pronóstico para los pacientes con metástasis regionales o a distancia es infausto con una supervivencia media de 24 y 6 meses respectivamente. ${ }^{2}$

La nueva clasificación de la American Joint Committee on Cancer (AJCC), oficial desde su publicación en el año 2002 incorpora nuevos factores pronósticos de forma más detallada, con el fin de realizar una estratificación más precisa de los pacientes (Tabla 1).6,7 Su complejidad refleja el debate actual y la multiplicidad de factores con implicación pronóstica en el melanoma cutáneo.

Los diferentes tipos clínico-morfológicos de $\mathrm{MC}$ no conllevan implícito un valor pronóstico. ${ }^{5,12}$ Aunque los MC situados en las regiones BANS no han demostrado tener más agresividad, la localización anatómica influye en el pronóstico. ${ }^{12}$ Los MC de la cabeza y el cuello presentan un peor pronóstico relativo, con una elevada incidencia de recurrencias y una alta mortalidad. 3,5,12 La causa podría radicar en la extrema delgadez de la piel de esta región, lo que motivaría que para un determinado espesor, el riesgo de invasión vascular y linfática fuese mayor. Dentro de la cabeza y el cuello se describe un peor pronóstico para los melanomas originados en el cuero
All patients are disease-free at the moment except one patient (case 4) who died 25 months after the treatment as a result of distant metastasis to the lungs. Curiously, she was the only patient to have complementary radiotherapy treatment.

\section{Discussion}

The considerable incidence of cutaneous melanoma (CM) in the head and neck, is attributed to many factors such as exposure to the sun and a distribution of melanocytes throughout the skin that is 2 to 3 times larger. 4,5 Survival in patients depends on a multiple of interrelated prognostic factors that can be summed up by the appropriateness of early diagnosis and treatment. While those patients with early stages of the disease have cure rates of over $90 \%$, the prognosis for patients with regional or distant metastasis is gloomy, with an average survival rate of 24 and 6 months respectively. ${ }^{2}$

The new classification of the American Joint Committee on Cancer (AJCC), published officially in the year 2002, incorporates new prognostic factors that are more detailed, with the aim of carrying out a more precise stratification of patients (Table 1).6,7 Its complexity reflects the current debate and the multiple factors implied in the prognosis of cutaneous melanoma.

The different clinical/morphologic types of CM do not carry an implicit prognostic value. ${ }^{5,12}$ Although the CM situated in the BANS region has not been demonstrated as more aggressive, the anatomic location influences the prognosis. ${ }^{12}$ The $C M$ of the head and neck have a relatively worse prognosis as there is a high recurrence rate and mortality is high.,3,12 The cause could lie in the skin being extremely fine in this area, which could lead to the risk of vascular and lymphatic spread being greater with a certain thickness. Within the area of the head and neck, a worse prognosis has been described for melanomas that originate in the scalp and cervical skin, while the prognosis is better for those originating in the external part of the ear and especially on the face.13,14 Unlike other tumors, with CM the size of the primary tumor does not have prognostic value. ${ }^{15}$ The T stage should be calculated initially by means of the histopathologic measurement of the thickness of the tumor, with a subclassification then being added that is called $a$ or $b$ according to there being ulceration or not. 6 This carries a worse prognosis, as there is an independent risk factor for developing an advanced form of the disease. ${ }^{16}$ Clark's level should still be reflected as it still provides prognostic information of fine tumors $(<1$ $\mathrm{mm}) .{ }^{6}$ Although a multitude of numbers have been proposed such as rupture point, tumor thickness, considered during decades as being the main factor determining prognosis, it presents a lineal correlation with survival and it should be treated as a continuous variable. ${ }^{17}$

Resection margins and the need for carrying out prophylactic lymphadenectomies of the head and neck are at the center of the debate on CM treatment. The current tendency 
Tabla 3. Relación de ganglios centinelas cervicofaciales localizados durante la la linfogammagrafía (LGG) y el tratamiento quirúrgico por niveles cervicales. Estudio histopatológico y color de los ganglios centinelas (AP+: ganglios con metástasis, AP-: ganglios libres de enfermedad metastásica). Tratamientos aplicados.

\begin{tabular}{|c|c|c|c|c|c|c|c|c|}
\hline \multicolumn{6}{|c|}{ Ganglios centinelas } & \multicolumn{3}{|c|}{ Tratamiento aplicado } \\
\hline $\begin{array}{l}\text { № } \\
\text { LGG }\end{array}$ & $\begin{array}{c}\text { № } \\
\text { cirugía }\end{array}$ & $\begin{array}{l}\text { Localización } \\
\text { (niveles y } n^{\circ} \text { ) }\end{array}$ & $\mathrm{AP}+$ & AP- & $\begin{array}{l}\text { Azul } \\
\text { colgajos }\end{array}$ & Reconstrucción & IT & RT \\
\hline 2 & 2 & $\begin{array}{l}\text { - Parotídeo (1) } \\
\text { - V (1) }\end{array}$ & 0 & 2 & No & Cervicofacial & No & No \\
\hline 4 & 4 & $\begin{array}{l}\text { Lado izquierdo: } \\
\text { - I (2): } 1 \text { facial y } 1 \text { submaxilar } \\
\text { - III (1) } \\
\text { Lado derecho }\end{array}$ & & & & & & \\
\hline & & $\bullet$ II (1) & 0 & 4 & 2 & Frontal + mucosos de labio & $\mathrm{Si}$ & $\mathrm{Si}$ \\
\hline 3 & 3 & - Parotídeos (3) & 0 & 3 & 0 & Cervicofacial & $\mathrm{Si}$ & $\mathrm{Si}$ \\
\hline 2 & 5 & - Parotídeos (5) & 0 & 5 & No & Mejilla avance & $\mathrm{Si}$ & No \\
\hline 5 & 5 & $\begin{array}{l}\text { - Parotídeos (2) } \\
\text { - II (1) }\end{array}$ & & & & & & \\
\hline & & $\bullet$ III (2) & 0 & 5 & No & Frontal rotación & $\mathrm{Si}$ & $\mathrm{Si}$ \\
\hline 1 & 1 & • V (1) & 0 & & No & Cierre directo & $\mathrm{Si}$ & $\mathrm{Si}$ \\
\hline
\end{tabular}

Tabla 3. List of sentinel lymph nodes of the head and neck located during the lymphoscintigraphy (LSG) and surgical treatment according to neck levels. Histopathologic study and color of the sentinel lymph nodes (AP+: lymph nodes with metastasis, AP: lymph node free of metastatic disease).

\begin{tabular}{|c|c|c|c|c|}
\hline \multicolumn{5}{|c|}{ Sentinel lymph nodes } \\
\hline $\begin{array}{l}\text { № } \\
\text { LSG }\end{array}$ & $\begin{array}{c}\text { № } \\
\text { surgery }\end{array}$ & $\begin{array}{c}\text { Location } \\
\text { (level and } \mathrm{n}^{\circ} \text { ) }\end{array}$ & $\mathrm{AP}+$ & AP- \\
\hline 2 & 2 & $\begin{array}{l}\text { - } \text { ß Parotid (1) } \\
\text { - V (1) }\end{array}$ & 0 & 2 \\
\hline \multirow[t]{2}{*}{4} & 4 & $\begin{array}{l}\text { Left side: } \\
\text { - I ( } 2 \text { ): } 1 \text { facial a } \\
\text { - III (1) } \\
\text { Righ side }\end{array}$ & & \\
\hline & & - II (1) & 0 & 4 \\
\hline 3 & 3 & - Parotid (3) & 0 & 3 \\
\hline 2 & 5 & - Parotid (5) & 0 & 5 \\
\hline \multirow[t]{2}{*}{5} & 5 & $\begin{array}{l}\text { - Parotid (2) } \\
\text { - II (1) }\end{array}$ & & \\
\hline & & • III (2) & 0 & 5 \\
\hline 1 & 1 & • V (1) & 0 & \\
\hline
\end{tabular}

\begin{tabular}{cccc}
\multicolumn{4}{c}{ Treatment applied } \\
$\begin{array}{c}\text { Blue } \\
\text { flap }\end{array}$ & Reconstruction & IT & RT \\
No & Cervicofacial & No & No \\
& & & \\
& & & \\
& & & \\
& & & Yes \\
2 & Frontal + lip mucosa & Yes & Yes \\
0 & Cervicofacial & Yes & Yes \\
No & & Yes & No \\
& & & \\
& Frontal rotation & Yes & Yes \\
No & Direct closure & Yes & Yes \\
No & &
\end{tabular}

IT: immunotherapy with interferon $a-2 b, R T$ : radiotherapy.

cabelludo y la piel cervical y mejor para los originados en el pabellón auricular y sobre todo en la cara. ${ }^{13,14}$

A diferencia de otros tumores, en el MC el tamaño del primario no presenta valor pronóstico. ${ }^{15}$ El estadio T debe calcularse inicialmente mediante la medición histopatológica del espesor tumoral, añadiendo una subclasificación designada como a o b en función de la presencia de ulceración. ${ }^{6}$ Esta conlleva un peor pronóstico, comportándose como un factor de riesgo independiente para el desarrollo de enfermedad avanzada. ${ }^{16}$ El nivel de Clark debe seguir reflejándose porque continúa proporcionando información pronóstica en los tumores delgados ( $<1 \mathrm{~mm}) .{ }^{6}$ Aunque se han propuesto multitud de cifras como punto ruptura, el espesor tumoral, considerado durante décadas el principal determinante pro- is to consider $1 \mathrm{~cm}$ as sufficient, with margins above this being unnecessary especially in our region where aesthetic and functional sequelae are more evident. ${ }^{18}$ The histopathological stage of regional lymph nodes is the main factor determining prognosis with this neoplasm, above Breslow's tumor thickness and any characteristic of the primary tumor, 6,13 as a result of which the AJCC advises that staging should always be carried out.

Those patients with metastasis in lymph nodes of the head and neck require a regional lymphadenectomy. Parotid nodes represent the first drainage point in most tumors located in the ear, face and anterior part of the scalp. If there is parotid lymph node metastasis, cervical dissection should be 
nóstico, presenta una correlación lineal con la supervivencia y debe ser tratado como una variable contínua. ${ }^{17}$

Los márgenes de resección y la necesidad de realizar linfadenectomías cervicofaciales profilácticas centran el debate en el tratamiento del MC. La tendencia actual es a considerar $1 \mathrm{~cm}$ como suficiente, siendo innecesarios márgenes superiores especialmente en nuestra región donde las secuelas estéticas y funcionales son más evidentes. ${ }^{18}$ El estado histopatológico de los ganglios linfáticos regionales es el principal determinante pronóstico de esta neoplasia, por encima del espesor tumoral de Breslow y cualquier característica del tumor primario, ${ }^{6,13}$ motivo por el cual la AJCC aconseja realizar siempre el estadiaje de los mismos.

Los pacientes con metástasis en los ganglios cervicofaciales requieren una linfadenectomía regional. Los ganglios parotídeos constituyen el primer lugar de drenaje en la mayoría de los tumores localizados en la oreja, la cara y el cuero cabelludo anterior. Si existen metástasis ganglionares parotídeas debe realizarse, además de la parotidectomía correspondiente, una disección cervical, por la elevada probabilidad de presentar metástasis en los ganglios linfáticos cervicales (entre el $47 \%$ y el $58 \%) .{ }^{19}$

Por el contrario, en los pacientes con enfermedad localizada (N0) el beneficio de las disecciones profilácticas sobre la supervivencia global continúa siendo uno de los aspectos más controvertidos. La linfadenectomía profiláctica persigue erradicar las micrometástasis ganglionares y aumentar así el porcentaje de curación. Mientras algunos estudios obtienen mejores resultados con la disección preventiva, ${ }^{20}$ otros no consiguen ningún beneficio apreciable. ${ }^{13}$ Fisher, ${ }^{13}$ en un fenomenal trabajo retrospectivo, analiza la supervivencia y los patrones de recurrencia en 1.444 pacientes con melanoma de cabeza y cuello en función de la disección cervical realizada de forma profiláctica, terapéutica o diferida hasta la aparición de metástasis. En el análisis multivariante observó una mejor supervivencia de los pacientes a los que sólo se les realizó la linfadenectomía tras la aparición de la metástasis (6,14 años de promedio, $56 \%$ vivos a los 5 años), en comparación con los que se les realizó de forma profiláctica evidenciándose metástasis en algún ganglio $(2,12$ años de promedio, 24\% vivos a los 5 años). Estos resultados sugieren que la linfadenectomía profiláctica no produce un impacto positivo en cuanto a supervivencia de los pacientes con metástasis ocultas; la disección diferida hasta que aparezcan metástasis clínicamente evidentes parece la mejor opción terapéutica. La causa de esto no está clara: posible y teóricamente, volúmenes microscópicos de tumor presentes durante largo tiempo en el interior del sistema linfático podrían estimular la respuesta inmune activando las células $\mathrm{T}$, de forma similar a una vacuna.

El estudio histopatológico de las linfadenectomías profilácticas, realizadas en pacientes afectos de $\mathrm{MC}$ de cabeza y cuello evidenciaron que sólo entre el 4-23\% (12\% de media) presentaban metástasis ganglionares. $5,20,21$ De esta manera, en el 77-96\% de los pacientes con cuello N0 éstas implican un sobretratamiento innecesario. Como consecuencia de todo lo expuesto, cuando no existe evidencia clínico-radiológica preoperatoria de metástasis cérvico-faciales (estadios clínicos T2, T3 y T4, N0, M0), la AJJCC y la UICC recomiendan imperativamente, realizar el estadiaje ganglionar regional mediante la linfadenectomía selectiva de los ganglios centinelas (GC). 7,10,11 carried out as well as the corresponding parotidectomy, as there is a high probability of there being metastasis in the cervical lymph nodes (between 47\% and 58\%). ${ }^{19}$

On the contrary, with patients with localized disease (NO) the advantages of prophylactic dissection on the global survival continues being one of the more controversial aspects. Prophylactic lymphadenctomy is aimed at eradicating micrometastatic lymph nodes in order to increase the cure rate. While some studies report obtaining better results with preventive dissection, ${ }^{20}$ others do not achieve any advantages that can be appreciated. ${ }^{13}$ Fisher, ${ }^{13}$ in a phenomenal retrospective work, analyzes survival and recurrence patterns in 1444 patients with melanoma of the head and neck according to the neck dissections carried out prophylactically, therapeutically or differed until the appearance of metastasis. In the multivariate analysis he observed better survival in patients that had only received a lymphadenectomy following the appearance of metastasis (6.14 years on average, $56 \%$ were alive 5 years later), compared with those that had this prophylactically with nodal metastasis being avoided (2.12 years on average, $24 \%$ were alive 5 years later). These results suggest that a prophylactic lymphadenectomy does not produce a positive impact with regard to the survival of patients with hidden metastasis; differing dissection until clinically evident metastasis appears to be the best therapeutic option. The cause of this is not clear: possibly and theoretically, microscopic tumor volumes that have been present over a long period of time within the lymphatic system could stimulate an immune response by activating $T$ cells, in the same way as vaccines.

The histopathologic study of prophylactic lymphadenectomies carried out in patients with CM of the head and neck showed that only between $4-23 \%$ (12\% on average) had ganglionic metastasis.3,20,21 This implies that $77-96 \%$ of patients with NO necks had unnecessary treatment. As a result of all this, when there is no preoperative clinical/radiological evidence of metastasis in the head and neck (clinical stages T2, T3 and T4, NO, MO), the AJJCC and the UICC are imperative about recommending regional lymph node staging by means of selective lymphadenectomies of sentinel lymph nodes (SN). $7,10,11$

The detection technique and biopsy of SN provides data that is so determinant that it has become the treatment of choice for carrying out regional lymph node staging $(N)$, with these results being incorporated into the latest version of the classification system of the CM.8,21,22 The size of the lymph nodes is therefore replaced by the number of lymph nodes that are affected and the tumor "weight" of these (microscopically versus macroscopically). These two pieces of data are the most important in survival prediction for patients with nodal disease, with two types of classification offered that are clinical and histopathologic. ${ }^{6}$ Survival decreases as the number of affected lymph nodes increases and/or the evidence is macroscopic. 
La técnica de detección y biopsia de los GC proporciona datos tan determinantes que se ha convertido en el procedimiento de elección para realizar el estadiaje ganglionar regional $(\mathrm{N})$, incorporándose sus resultados en la última versión del sistema de clasificación del MC.8,21,22 En él, el tamaño de los ganglios linfáticos se reemplaza por el número de ganglios linfáticos afectos y la «carga» tumoral de los mismos (microscópico versus macroscópico). Estos dos datos son los predictores más importantes de supervivencia en los pacientes con enfermedad ganglionar, ofreciendo 2 tipos de clasificación, clínica e histopatológica. ${ }^{6}$ La supervivencia disminuye a medida que el número de ganglios afectos aumenta y/o la afectación es macroscópica.

Datos recientes de múltiples trabajos confirman la eficacia de la técnica con alta sensibilidad, especificidad y seguridad diagnóstica para detectar metástasis subclínicas con muy bajas tasas de falsos negativos y complicaciones. ${ }^{10,21}$ Nuestros resultados avalan que la técnica es predecible y fiable en estos tumores, aportando datos muy importantes para valorar el pronóstico y la necesidad de terapéuticas adyuvantes.

Las linfadenectomías selectivas de los GC presentan ventajas evidentes sobre las disecciones clásicas. Por una parte al realizar un estudio más exhaustivo de los ganglios linfáticos (seccionamiento múltiple e inmunohistoquímica), permite identificar la presencia de metástasis ganglionares microscópicas y realizar un estadiaje cervical más preciso ${ }^{6-11}$ (el estudio histopatológico estándar, una sección de cada mitad ganglionar, presenta un elevado riesgo de no identificar las metástasis microscópicas). ${ }^{23}$ Por otra parte, evita la morbilidad de las disecciones ganglionares cervicofaciales innecesarias, reduciendo el coste económico y mejorando la calidad de vida de los pacientes.8,10,24 Aunque los pacientes con afectación metastásica en algún GC precisan una linfadenectomía terapéutica en un segundo acto quirúrgico, ésta sería realizada también en un estadio precoz de la enfermedad.

La linfadenectomía selectiva cervicofacial es más delicada que en otras regiones..$^{10}$ La complejidad de las vías de drenaje de la cabeza y el cuello, la multiplicidad y amplia distribución de los GC, junto con su frecuente localización intraparotídea, con riesgo para el nervio facial, hacen difícil su ejecución. ${ }^{9-11,25}$ El elevado promedio de GC encontrados por nosotros en cada paciente (3,3 GC repartidos en varias regiones linfáticas) demuestra el rico drenaje linfático de esta región y concuerda con los obtenidos por otros autores (entre 1,5 y 3,6 GC por paciente, con promedios de $2,67,232,8,25$ y $3,6,{ }^{10}$ repartidos también en varias regiones linfáticas 2,2$).{ }^{10}$ Un dato muy importante y sorprendente es que el $55 \%$ de los GC eran peri e intraparotídeos y en el $66 \%$ de nuestros pacientes se evidenció algún GC en esta localización. Otros autores, ${ }^{10,25}$ obtienen cifras significativas aunque ligeramente inferiores (entre 25,25 y $44 \%, 10$ de los pacientes), resaltando su pequeño tamaño (entre 3 y $4 \mathrm{~mm}$ ), la dificultad para su identificación y el elevado riesgo de lesionar el nervio facial.

El seccionamiento múltiple es imprescindible en el estudio histológico para conseguir unos resultados fiables, pues en la mayoría de los pacientes el foco de enfermedad metastásica es muy pequeño (mide $4 \mathrm{~mm}$ o menos). ${ }^{10}$ Aunque las técnicas de inmunohistoquímica (HMB-45, S-100 y Melan A) pueden ayudar a identificar
Recent data of multiple works confirms the efficiency of the technique with high sensitivity, specificity and diagnostic reliability for detecting subclinical metastasis with very low rates of false negatives and complications. 10,21 Our results show that this technique is predictable and reliable for these tumors, and that very important data is provided for evaluating prognosis and the need for adjuvant therapy.

Selective lymphadenectomies of $S N$ have obvious advantages over classical dissections. On the one hand carrying out a more exhaustive study of lymph nodes (multiple selection and immunohistochemistry), allows identifying the presence of microscopic lymph node metastasis and carrying out neck staging that is more precise ${ }^{6-11}$ (the standard histopathologic study, a section of every lymph node half, carry a high risk of not identifying microscopic metastasis). ${ }^{23}$

This also avoids morbidity due to the unnecessary dissection of lymph nodes of the head and neck, financial cost is reduced and patients have better quality of life. $8,10,24$ Although patients with metastasis in a $\mathrm{SN}$ require therapeutic lymphadenectomies in a second surgical act, this should be carried out in an earlier stage of the disease.

A lymphadenectomy of the head and neck is more delicate than in other regions. ${ }^{10}$ The drainage pathways of the head and neck, the multiplicity and ample distribution of the $\mathrm{SN}$, together with its frequent intraparotid location with risk to the facial nerve, make carrying this out difficult.9-11,25 The high average of SN that we found in each patient (3.3 SN distributed across various lymphatic regions) shows the rich lymphatic drainage in this region, coinciding with that obtained by other authors (between 1.5 and $3.6 \mathrm{SN}$ per patient with a mean of $2.67,232.8,{ }^{25}$ and $3.6,{ }^{10}$ distributed across various lymphatic regions 2.2).10 There is very important data that is surprising in that $55 \%$ of the $\mathrm{SN}$ were periparotid and intraparotid and in $66 \%$ of our patients there was a SN in this location. Other authors, 10,25 obtain significant numbers although these are slightly lower (between $25 \%, 25$ and $44 \%,{ }^{10}$ of patients), of note being their small size (between 3 and $4 \mathrm{~mm}$ ), the difficulty in identifying them and the high risk of harming the facial nerve.

Multiple selection is essential in histologic studies in order to achieve reliable results, as in most patient the metastatic disease center is very small (measuring $4 \mathrm{~mm}$ or less). ${ }^{10}$ Although immunochemical techniques (TIM-45, S-100 and Melan A) can aid in identifying metastatic foci that have gone unnoticed in the hematoxylin and eosin analysis, today micrometastatic diagnosis requires identification by means of this last type of staining. Intraoperative biopsies by means of sectioning and freezing is not justifiable given the high incidence of false negatives (53\%). The absence of metastasis in our $\mathrm{SN}$ may be a reflection of our limited samples and the early diagnosis of our patients. Larger samples show rates of $15 \%, 29$ and $21 \%, 10$ of $\mathrm{NN}$ with metastasis, which is the equivalent of $20 \%$ of patients.

The intraoperative mapping of $\mathrm{SN}$ by means a surgical gamma probe is so reliable, that many authors ${ }^{10}$ claim that 
focos metastásicos que hayan pasado inadvertidos en el análisis mediante hematoxilina y eosina, hoy en día el diagnóstico de micrometástasis precisa de su reconocimiento mediante esta última tinción. La biopsia intraoperatoria mediante sección-congelación no es justificable por su alto índice de falsos negativos (53\%). La ausencia de metástasis en nuestros GC quizá sea el reflejo de la escasez de muestra y el diagnóstico precoz de nuestros pacientes. Muestras mayores evidencian entre un $15 \%,{ }^{25}$ un $21 \%,{ }^{10}$ de GC con metástasis, correspondientes al $20 \%$ de los pacientes.

La excelente fiabilidad de la detección intraoperatoria de los GC mediante la sonda quirúrgica gamma, permite afirmar a varios autores, ${ }^{10}$ y es también nuestra impresión, que la linfogammagrafía preoperatoria puede llegar a ser innecesaria en equipos experimentados. Además del posible entorpecimiento de la cirugía y el riesgo de reacciones anafilácticas, parece existir consenso, en la literatu$\mathrm{ra},{ }^{10}$ acerca de la poca efectividad del uso de colorantes vitales para la detección de los GC.

\section{Conclusión}

La técnica de detección y biopsia de los GC regionales se considera el procedimiento de elección para realizar el estadiaje ganglionar regional en el melanoma cutáneo de cabeza y cuello. Permite mejorar la identificación preoperatoria de los patrones de drenaje linfático aberrantes, aumentando la eficacia y sensibilidad del estudio histopatológico, al seleccionar los ganglios linfáticos cervicofaciales con mayor probabilidad de encontrar focos metastásicos ganglionares subclínicos (micrometástasis).

\section{Bibliografía}

1. Lentsch EJ, Myers JN. Melanoma of the head and neck: Current concepts in diagnosis and management. Laryngoscope 2001;111:1209-22.

2. Mackie RM, Bray CA, Hole DJ, Morris A, Nicolson M, Evans A, Doherty V, Vestey J. Incidence of and survival from malignant melanoma in Scotland: an epidemiological study. Lancet 2002;360:587-91.

3. White MJ, Polk HC. Therapy of primary cutaneous melanoma. Med Clin North Am 1998;135:1472-6.

4. Goldsmith HS. Melanoma: an overview. Cancer 1979;29:194-7.

5. O'Donnell MJ, Whitaker DC. Clinical evaluation of tumors of the skin. En: Comprehensive Management of Head and Neck Tumors. Volumen 2. Thawley SE, Panje WR, Batsakis JG, Lindberg RD Eds. W.B. Saunders Company. Philadelphia. 1999;1222-46.

6. Kim CJ, Reintgen DS, Balch CM. The new melanoma staging system. Cancer Control 2002;9(1):9-15.

7. Balch CM, Mihm MC. Reply to the article «The AJCC staging proposal for cutaneous melanoma: comments by the EORTC Melanoma Group», by D.J. Ruiter y cols. (Ann Oncol 2001; 12: 9-11). Ann Oncol 2002;13:175-6.

8. Belhocine T, Pierard G, Labrassinne M, Lahaye T, Rigo P. Staging of regional nodes in AJCC stage I and II melanoma: ${ }^{18 F D G ~ P E T ~ i m a g i n g ~ v e r s u s ~ s e n t i n e l ~ n o d e ~}$ detection. The Oncologist 2002;7:271-8.

9. Lentsh EJ, McMasters KM. Sentinel lymph node biopsy for melanoma of the head and neck. Expert Rev Anticancer Ther 2003;3:673-83. a preoperative lymphoscintigraphy may soon be unnecessary for experienced teams, this also being our impression. In addition to the possible drawbacks in surgery and the risk of anaphylactic reactions, there is consensus in the literature ${ }^{10}$ as to the lack of effectiveness or vital staining for mapping SN.

\section{Conclusion}

The technique for the detection and biopsy of regional $S \mathrm{~N}$ is considered the procedure of choice for carrying out regional ganglionic staging in cutaneous melanoma of the head and neck. Preoperative identification of aberrant lymphatic drainage patterns is improved and the efficiency and sensitivity of histopathologic studies, as the lymph nodes of the head and neck with a greater probability of having subclinical metastatic node foci (micrometastasis) are selected. 
10. Eicher SA, Clayman GL, Myers JN, Gillenwater AM. A prospective study of intraoperative lymphatic mapping for head and neck cutaneous melanoma. Arch Otolaryngol Head Neck Surg 2002;128:241-6.

11. Morris KT, Stevens JS, pommier RF, Fletcher WS, Vetto JT. Usefulness of preoperative lymphoscintigraphy for the identification of sentinel lymph nodes in melanoma. Am / Surg 2001;181:423-6.

12. Brown M. Staging and prognosis of melanoma. Seminars in Cutaneous Medicine and Surgery 1997;16:113-21.

13. Fisher SR. Elective, therapeutic, and delayed lymph node dissection for malignant melanoma of the head and neck: analysis of 1444 patients from 1970 to 1988. Laryngoscope 2002;112:99-110.

14. Urist MM, Balch CM, Soong SJ, y cols. Head and neck melanomas in 536 clinical stage I patients: a prognostic factors analysis and results of surgical treatment. Ann Surg 1984;200:769-75.

15. Karakousis CP, Emrich LJ, Rao U. Tumor thickness and prognosis in clinical stage I malignat melanoma. Cancer 1989;64:1432-6.

16. McGovern VJ, Shaw HM, Milton GW, y cols. Ulceration and prognosis in cutaneous malignant melanoma. Histopatology 1982;6:399-407.

17. Buttner P, Garbe C, Bertz J, y cols. Primary cutaneous melanoma : optimized cutoff points of tumor thickness and importance of Clark's level for prognostic classification. Cancer 1995;75:2499-506.

18. Versoni U, Cascinelli N. Narrow escisión (1 cm margin): a safe procedure for thin cutaneous melanoma. Arch Surg 1991;126:438-41.
19. O'Brien CJ, Mcneil EB, McMahon JD, Pathak I, Lauer CS. Incidence of cervical node involvement in metastatic cutaneous malignancy involving the parotid gland. Head Neck 2001;23:744-8.

20. Renner GJ, Gaston DA, Clark DP. Controversy in the management of tumors of the skin. En: Comprehensive Management of Head and Neck Tumors. Volumen 2. Thawley SE, Panje WR, Batsakis JG, Lindberg RD Eds. W.B. Saunders Company. Philadelphia 1999;130919.

21. Mariani G, Erba P, Manca G, y cols. Radioguided sentinel lymph node biopsy in patients with malignant cutaneous melanoma: the nuclear medicine contribution. J Surg Oncol 2004;85:141-51.

22. Balch CM, Buzaid AC, Soong SJ, y cols. Final version of the American Joint Committee on Cancer staging system for cutaneous melanoma. / Clin Oncol 2001;19:3635-48.

23. Davison SP, Clifton MS, Kauffman L, Minasian L. Sentinel node biopsy for the detection of the head and neck melanoma. A review. Ann Plastic Surg 2001;47: 206-11.

24. Pathak I, O'Brien CJ, Petersen-Schaeffer K, y cols. Do nodal metastases from cutaneous melanoma of the head and neck follow a clinically predictable pattern? Head Neck 2001;23:785-90.

25. Chao C, Wong SL, Edwards MJ, y cols. Sentinel lymph node biopsy for head and neck melanomas. Ann Surg Oncol 2003;10:21-6. 